\title{
MODEL PEMBELAJARAN CREATIVE PROBLEM SOLVING DENGAN VIDEO COMPACT DISK UNTUK MENCAPAI KOMPETENSI DASAR DALAM PEMBELAJARAN MATEMATIKA DI MTS
}

\author{
Saminanto ${ }^{1}$
}

\begin{abstract}
Abstrak:
Matematika adalah mata pelajaran yang diajarkan dari jenjang pendidikan dasar sampai pendidikan menengah. Selain mempunyai sifat yang abstrak, pemahaman konsep matematika yang baik sangatlah penting karena untuk memahami konsep yang baru diperlukan prasarat pemahaman konsep sebelumnya. Dalam proses belajar mengajar guru mempunyai tugas untuk memilih model pembelajaran berikut media yang tepat sesuai dengan materi yang disampaikan demi tercapainya tujuan pembelajaran. Sampai saat ini masih banyak ditemui kesulitan siswa untuk mempelajari konsep geometri, antara lain tentang persegi panjang dan persegi pada siswa kelas VII semester 2. Akibatnya terjadi kesulitan siswa untuk memahami konsep geometri selanjutnya karena konsep prasarat belum dipahami. Model pembelajaran Creative Problem Solving dengan Media Video Compact Disk sangat dimungkinkan bisa meningkatkan pemahaman konsep, keaktifan, dan hasil belajar siswa. Model pembelajaran ini dapat dijadikan alternatif pada

${ }^{1}$ Penulis adalah Dosen Fakultas Tarbiyah IAIN Walisongo, Sekertaris Prodi Tadris Matematika.
\end{abstract}


pembelajaran matematika karena sesuai dengan karakteristik matematika dan tuntutan Kurikulum 2006. Penelitian tindakan kelas/penelitian perbaikan pembelajaran ini mengambil obyek Kota Semarang, dan mengambil sampel di MTsN 1 Kota Semarang. Data yang diperoleh diolah secara deskriptif.

Pelaksanaan penelitian dibagi dalam dua siklus, yang tiap siklusnya terdiri dari perencanaan, pelaksanaan, pengamatan dan refleksi. Hasil pengamatan dan refleksi akan dijadikan bahan rujukan untuk pelaksanaan siklus berikutnya. Sehingga proses dan hasil pelaksanaan siklus berikutnya diharapkan akan lebih baik dari siklus sebelumnya. Dari tiap siklus akan diukur proses keaktifan dan proses bermain peran, dan keberhasilan siswa dalam pembelajaran dengan model pembelajaran creative problem solving dengan media video compact disk.

Hasil penelitian menunjukan bahwa pembelajaran matematika menggunakan model pembelajaran creative problem solving dengan media video compact disk dapat meningkatkan pemahaman konsep, keaktifan, dan hasil belajar siswa di MTs.

Kata Kunci: Problem Solving, Kreatif, VCD 


\section{A. PENDAHULUAN}

Matematika merupakan suatu mata pelajaran yang diajarkan pada setiap jenjang pendidikan di Indonesia mulai dari Sekolah Dasar (SD) sampai dengan Sekolah Menengah Atas (SMA). Karena pendidikan merupakan salah satu hal penting untuk menentukan maju mundurnya suatu bangsa, maka untuk menghasilkan sumber daya manusia sebagai subyek dalam pembangunan yang baik, diperlukan modal dari hasil pendidikan itu sendiri. Khusus untuk mata pelajaran matematika, selain mempunyai sifat yang abstrak, pemahaman konsep yang baik sangatlah penting karena untuk memahami konsep yang baru diperlukan prasarat pemahaman konsep sebelumnya.

Dalam proses belajar mengajar di kelas terdapat keterkaitan yang erat antara guru, siswa, kurikulum, sarana dan prasarana. Guru mempunyai tugas untuk memilih model dan media pembelajaran yang tepat sesuai dengan materi yang disampaikan demi tercapainya tujuan pendidikan. Sampai saat ini masih banyak ditemukan kesulitan-kesulitan yang dialami siswa di dalam mempelajari matematika. Salah satu kesulitan itu adalah memahami konsep tentang syarat melukis segitiga pada siswa kelas VII semester 2. Akibatnya terjadi kesulitan siswa untuk memahami konsep berikutnya karena konsep prasarat belum dipahami.

Menurut H.W. Fowler dalam Pandoyo (1997:1) matematika merupakan mata pelajaran yang bersifat abstrak, sehingga dituntut kemampuan guru untuk dapat mengupayakan metode yang tepat sesuai dengan tingkat perkembangan mental siswa. Untuk itu diperlukan model dan media pembelajaran yang dapat membantu siswa untuk mencapai kompetensi dasar dan indikator pembelajaran.

Menurut Sobel dan Maletsky dalam bukunya Mengajar Matematika (2001:1-2) banyak sekali guru matematika yang menggunakan waktu pelajaran dengan kegiatan membahas tugas-tugas lalu, memberi pelajaran baru, memberi tugas kepada siswa. Pembelajaran seperti di atas yang rutin dilakukan hampir tiap hari dapat dikategorikan sebagai 3M, yaitu membosankan, 
membahayakan dan merusak seluruh minat siswa.

Apabila pembelajaran seperti ini terus dilaksanakan maka kompetensi dasar dan indikator pembelajaran tidak akan dapat tercapai secara maksimal. Selain itu pemilihan media yang tepat juga sangat memberikan peranan dalam pembelajaran. Selama ini media pembelajaran yang dipakai adalah papan tulis, penggaris dan kapur dengan cara guru menggambar segitiga di papan tulis. Kalaupun menggunakan alat peraga berupa bangun segitiga dari karton atau segitiga dari lidi. Tetapi seiring dengan berkembangnya teknologi, media pembelajaran tersebut kurang menarik perhatian dan minat siswa. Untuk itu diperlukan suatu media pembelajaran yang dapat lebih menarik perhatian dan minat siswa tanpa mengurangi fungsi media pembelajaran secara umum.

Berdasarkan informasi yang diperoleh melaui pertemuan musyawarah guru mata pelajaran (MGMP) bidang studi matematika SMP dan MTs. pada umumnya mereka mengeluhkan siswanya berada jauh pada kenyataan yang diharapkan. Lebih jauh berdiskusi dengan guru SMP dan MTs baik swasta dan negeri di Kota Semarang mengenai keadaan siswanya dalam belajar matematika, menyatakan bahwa minat/semangat siswa dalam melaksanakan tugas guru, daya tangkap siswa dalam menerima pelajaran, kemampuan siswa dalam menghubungkan materi pelajaran dengan dunia nyata, kemampuan siswa dalam belajar mandiri, kemampuan siswa dalam menuliskan ide, kemampuan siswa dalam mengerjakan tugas mandiri, keberanian siswa dalam menyajikan temuan, ketrampilan siswa menulis dipapan tulis, dirasa masih rendah belum sesuai dengan kompetensi yang diharapkan dan belum sesuai dengan apa yang dikehendaki oleh matematika itu sendiri yaitu siswa mampu belajar mandiri, mengembangkan sense of mathematics, dan memiliki kemampuan berpikir tinggi (higher level thinking).

Hal ini lebih khusus pada siswa belajar dan memahami konsep syarat melukis segitiga, siswa banyak mengalami kesulitan dalam memehami konsep syarat melukis segitiga. Kegiatan pembelajaran di kelas dan kegiatan siswa secara individu, masih 
sangat ditentukan dan bergantung oleh guru. Hal ini juga ditunjukan dari hasil belajar pada tes sumatif materi tersebut ratarata dari tahun ketahun selalu dibawah hasil ketuntasan belajar minimal yang ditentukan yaitu 60 .

Model Pembelajaran Creative Problem Solving adalah suatu model pembelajaran yang memusatkan pada pengajaran dan ketrampilan pemecahan masalah, yang diikuti dengan penguatan ketrampilan (K.L. Pepkin, 2004:1). Dengan menggunakan model pembelajaran ini diharapkan dapat menimbulkan minat sekaligus kreativitas dan motivasi siswa dalam mempelajari matematika, sehingga siswa dapat memperoleh manfaat yang maksimal baik dari proses maupun hasil belajarnya.

Pemilihan media pembelajaran dengan menggunakan VCD dikarenakan akhir-akhir ini di lingkungan akademis atau pendidikan penggunaan media pembelajaran yang berbentuk VCD bukan merupakan hal yang baru lagi. Penggunaan media pembelajaran matematika yang berbentuk VCD memungkinkan digunakan dalam berbagai keadaan tempat, baik di sekolah maupun di rumah; serta yang paling utama adalah dapat memenuhi nilai atau fungsi media pembelajaran secara umum. Berdasarkan latar belakang tersebut di atas, maka judul yang dipilih dalam penelitian ini adalah "Penggunaan Model Pembelajaran Creative Problem Solving Dengan Media Video Compact Disk untuk mencapai kompetensi dasar dalam pembelajaran matematika di MTs".

\section{B. LANDASAN TEORI}

1. Teori Belajar Matematika

Menurut J. Bruner dalam Hidayat (2004:8) belajar merupakan suatu proses aktif yang memungkinkan manusia untuk menemukan hal-hal baru diluar informasi yang diberikan kepada dirinya. Pengetahuan perlu dipelajari dalam tahap-tahap tertentu agar pengetahuan itu dapat diinternalisasi dalam pikiran (struktur kognitif) manusia yang mempelajarinya. Proses internalisasi akan terjadi secara sungguh-sungguh (yang berarti proses belajar mengajar terjadi secara optimal) jika pengetahuan itu dipelajari dalam tahap-tahap sebagai berikut: 
a. Tahap Enaktif

Suatu tahap pembelajaran di mana pengetahuan dipelajari secara aktif dengan menggunakan benda-benda konkret atau situasi yang nyata.

b. Tahap Ikonik

Suatu tahap pembelajaran di mana pengetahuan direpresentasikan (diwujudkan) dalam bentuk bayangan visual (visual imagery), gambar atau diagram yang menggambarkan kegiatan konkret atau situasi konkret yang terdapat pada tahap enaktif.

c. Tahap Simbolik

Suatu tahap pembelajaran di mana pengetahuan itu direpresentasikan dalam bentuk simbol-simbol abstrak, baik si mbol-simbol verbal (misalkan huruf-huruf, katakata atau kalimat-kalimat), lambang-lambang matematika maupun lambang-lambang abstrak lainnya (Hidayat, 2004:9)

Suatu proses belajar akan berlangsung secara optimal jika pembelajaran diawali dengan tahap enaktif, dan kemudian jika tahap belajar yang pertama ini dirasa cukup, siswa beralih ke tahap belajar yang kedua, yaitu tahap belajar dengan menggunakan modus representasi ikonik. Selanjutnya kegiatan belajar itu dilanjutkan pada tahap ketiga, yaitu tahap belajar dengan menggunakan modus representasi simbolik.

\section{Pembelajaran Matematika}

Pembelajaran adalah upaya untuk menciptakan iklim dan pelayanan terhadap kemampuan, potensi, minat, bakat dan kebutuhan peserta didik yang beragam agar terjadi interaksi optimal antara guru dengan siswa serta antara siswa dengan siswa (Suyitno, 2004:1).

Agar tujuan pengajaran dapat tercapai, guru harus mampu mengorganisir semua komponen sedemikian rupa sehingga antara komponen yang satu dengan lainnya dapat berinteraksi secara harmonis( Suhito, 2000:12). Salah satu komponen dalam 
pembelajaran adalah pemanfaatan berbagai macam strategi dan metode pembelajaran secara dinamis dan fleksibel sesuai dengan materi, siswa dan konteks pembelajaran (Depdiknas, 2003:1). Sehingga dituntut kemampuan guru untuk dapat memilih model pembelajaran serta media yang cocok dengan materi atau bahan ajaran.

Dalam pembelajaran matematika salah satu upaya yang dilakukan oleh guru adalah dengan menggunakan model pembelajaran yang berbasis masalah (Problem Solving) karena dengan menggunakan model pembelajaran ini dapat memberikan siswa kesempatan seluas-luasnya untuk memecahkan masalah matematika dengan strateginya sendiri. Sedangkan penggunaan media dalam pembelajaran matematika sangat menunjang, karena dengan menggunakan media pembelajaran siswa lebih mudah memahami konsep matematika yang abstrak.

\begin{tabular}{lcccrr}
\multicolumn{2}{c}{ Kurikulum } & Tingkat & Satuan Pendidikan & (Kuri- \\
kulum & 2006) & yang & berakarkan pada & Kuriku- \\
lum & Berbasis & Kompetensi & (Kurikulum & 2004)
\end{tabular}
(Depdiknas, 2003:8) menyatakan bahwa potensi siswa harus dapat dikembangkan secara optimal dan di dalam proses belajar matematika siswa dituntut untuk mampu:

1. Melakukan kegiatan penelusuran pola dan hubungan,

2. Mengembangkan kreatifitas dengan imajinasi, intuisi dan penemuannya,

3. Melakukan kegiatan pemecahan masalah,

4. Mengkomunikasikan pemikiran matematisnya kepada orang lain.

Untuk mencapai kemampuan tersebut perlu dikembangkannya proses belajar matematika yang menyenangkan, memperhatikan keinginan siswa, membangun pengetahuan dari apa yang diketahui siswa, menciptakan suasana kelas yang mendukung kegiatan belajar, memberikan kegiatan yang sesuai dengan tujuan pembelajaran, memberikan kegiatan yang menantang, memberikan kegiatan yang memberi harapan keberhasilan, menghargai setiap pencapaian siswa (Depdiknas, 2003:5).

Selain itu di dalam mempelajari matematika siswa memer- 
lukan konteks dan situasi yang berbeda-beda sehingga diperlukan usaha guru untuk:

1. Menyediakan dan menggunakan berbagai alat peraga atau media pembelajaran yang menarik perhatian siswa,

2. Memberikan kesempatan belajar matematika di berbagai tempat dan keadaan,

3. Memberikan kesempatan menggunakan metematika untuk berbagai keperluan,

4. Mengembangkan sikap menggunakan matematika sebagai alat untuk memecahkan matematika baik di sekolah maupun di rumah,

5. Menghargai sumbangan tradisi, budaya dan seni di dalam pengembangan matematika,

6. Membantu siswa menilai sendiri kegiatan matematikanya.( Depdiknas, 2003:6)

Dari kurikulum di atas dapat dikatakan bahwa guru dalam melakukan pembelajaran matematika harus bisa membuat situasi yang menyenangkan, memberikan alternatif penggunaan alat peraga atau media pembelajaran yang bisa digunakan pada berbagai tempat dan keadaan, baik di sekolah maupun di rumah.

\section{Creative Problem Solving dalam Pembelajaran Matema- tika}

Model "Creative Problem Solving" (CPS) adalah suatu model pembelajaran yang melakukan pemusatan pada pengajaran dan keterampilan pemecahan masalah, yang diikuti dengan penguatan ketrampilan. Ketika dihadapkan dengan suatu pertanyaan, siswa dapat melakukan keterampilan memecahkan masalah untuk memilih dan mengembangkan tanggapannya. Tidak hanya dengan cara menghafal tanpa dipikir, keterampilan memecahkan masalah memperluas proses berpikir (Pepkin, 2004:1)

Suatu soal yang dianggap sebagai "masalah" adalah soal yang memerlukan keaslian berpikir tanpa adanya contoh penyelesaian sebelumnya. Masalah berbeda dengan soal latihan. 
Pada soal latihan, siswa telah mengetahui cara menyelesaikannya, karena telah jelas antara hubungan antara yang diketahui dengan yang ditanyakan, dan biasanya telah ada contoh soal.

Pada masalah siswa tidak tahu bagaimana cara menyelesaikannya, tetapi siswa tertarik dan tertantang untuk menyelesaikannya. Siswa menggunakan segenap pemikiran, memilih strategi pemecahannya, dan memproses hingga menemukan penyelesaian dari suatu masalah (Suyitno, 2000:34).

Adapaun proses dari model pembelajaran JPS, terdiri dari langkah-langkah sebagai berikut:

a. Klarifikasi masalah

Klarifikasi masalah meliputi pemberian penjelasan kepada siswa tentang masalah yang diajukan, agar siswa dapat memahami tentang penyelesaian seperti apa yang diharapkan.

b. Pengungkapan pendapat

Pada tahap ini siswa dibebaskan untuk mengungkapkan pendapat tentang berbagai macam strategi penyelesaian masalah.

c. Evaluasi dan Pemilihan

Pada tahap evaluasi dan pemilihan ini, setiap kelompok mendiskusikan pendapat-pendapat atau strategi-strategi mana yang cocok untuk menyelesaikan masalah.

d. Implementasi.

Pada tahap ini siswa menentukan strategi mana yang dapat diambil untuk menyelesaikan masalah, kemudian menerapkannya sampai menemukan penyelesaian dari masalah tersebut (Pepkin, 2004:2).

Dengan membiasakan siswa menggunakan langkah-langkah yang kreatif dalam memecahkan masalah, diharapkan dapat membantu siswa untuk mengatasi kesulitan dalam mempelajari matematika.

\section{Media Pembelajaran Matematika}

Menurut H.W. Fowler (Suyitno, 2000:1) matematika adalah 
ilmu yang mempelajari tentang bilangan dan ruang yang bersifat abstrak. Sehingga untuk menunjang kelancaran pembelajaran disamping pemilihan metode yang tepat juga perlu digunakan suatu media pembelajaran yang sangat berperan dalam membimbing abstraksi siswa (Suyitno, 2000:37).

Menurut Darhim(1993:10) adapun nilai atau fungsi khusus media pendidikan matematika antara lain:

1. Untuk mengurangi atau menghindari terjadinya salah komunikasi,

2. Untuk membangkitkan minat atau motivasi belajar siswa,

3. Untuk membuat konsep matematika yang abstrak, dapat disajikan dalam bentuk konkret sehingga lebih dapat dipahami, dimengerti dan dapat disajikan sesuai dengan tingkat-tingkat berpikir siswa.

Jadi salah satu fungsi media pembelajaran matematika adalah untuk meningkatkan motivasi belajar siswa. Sedangkan motivasi dapat mengarahkan kegiatan belajar, membesarkan semangat belajar juga menyadarkan siswa tentang proses belajar dan hasil akhir. Sehingga dengan meningkatnya motivasi belajar siswa dapat meningkatkan hasil belajarnya pula (Dimyati, 1994:78-79).

\section{Penggunaan VCD ( video Compact Disc ) dalam Pembela- jaran matemataika}

Seiring dengan berkembangnya ilmu pengetahuan dan teknologi, berkembang pula jenis-jenis media pembelajaran yang lebih menarik dan dapat digunakan baik di sekolah maupun di rumah. Salah satunya adalah media pembelajaran yang berbentuk VCD (Video Compact Disc).

Penggunaan VCD (Video Compact Disc) dapat digunakan sebagai alternatif pemilihan media pembelajaran matematika yang cukup mudah untuk dilaksanakan. Hal ini dikarenakan akhir-akhir ini di lingkungan akademis atau pendidikan penggunaan media pembelajaran yang berbentuk VCD bukan meru- 
pakan hal yang baru lagi dan dapat digunakan dalam kegiatan pembelajaran baik di sekolah maupun di rumah. Penggunaan media pembelajaran matematika yang berbentuk VCD memungkinkan digunakan di rumah karena VCD player sekarang ini sudah bukan merupakan barang mewah lagi dan dapat ditemukan hampir disetiap rumah siswa.

\section{Hasil Belajar dan Faktor-Faktor Yang Mempengaruhi}

Dari beberapa pendapat baik menurut Mulyono Abdurrahm, Keller, Nana Sudjana, dapat disimpulkan bahwa hasil belajar adalah kemampuan-kemampuan yang dimiliki siswa setelah ia menerima pengalaman belajar yang diperoleh melalui usaha dalam menyelesaikan tugas-tugas belajar.

Adapun hasil belajar/kompetisi dalam pembelajaran matematika yang harus dicapai sebagai berikut ( Erman Suherman 2003:17)

a. Menunjukan permasalahan dan keterkaitan antara konsep matematika yang dipelajari, serta mengaplikasikan konsep algoritma secara luwes, akurat, efesien dan tepat dalam pemecahan masalah.

b. Memiliki kemampuan mengkomunikasikan gagasan dengan symbol, tabel, grafik atau diagram untuk menjelaskan keadaan atau masalah.

c. Mengguanakan penalaran pada pola, sifat atau melakukan manipulasi metematika dan membuat generalisasi, menyusun bukti atau menjelaskan gagasan dan pertanyaan matematika.

d. Kemampuan berpikir tinggi diperlukan agar siswa memiliki kemampuan untuk menemukan/discovery penyelesaian problem-problem matematika di jenjangnya

e. Menunjukan kemampuan strategi dalam membuat (merumuskan), menafsirkan dan menyelesaikan metode matematika dalam pemecahan masalah.

f. Memiliki sikap menghargai kegunaan matematika dalam kehidupan. 
Hasil belajar akan dipengaruhi oleh banyak faktor. Dari sekian banyak faktor yang mempengaruhi hasil belajar baik itu menurut Muhibbin Syah, Slamet, Sumardi Suryabrata, dapat digolongkan menjadi tiga macam, sebagaiamana yang dikatakan oleh Abu Ahmadi yaitu:

a. Faktor-faktor stimulasi belajar.

Segala sesuatu di luar individu yang merangsang individu untuk mengadakan reaksi atau perbuatan belajar dikelompokkan dalam faktor stimuli belajar antar lain; Panjangnya bahan pelajaran, kesulitan bahan pelajaran, berartinya bahan pelajaran, berat ringannya tugas, suasana lingkungan eksternal.

b. Faktor-faktor metode balajar.

Metode belajar yang dipakai guru sangat mempengaruhi metode belajar yang dipakai oleh si pelajar, faktor-faktor metode belajar menyangkut hal-hal berikut; kegiatan berlatih atau praktek, overlearning dan drill, resitasi belajar, pengenalan tentang hasil-hasil belajar, belajar dengan keseluruhan dan dengan bagian-bagian, penggunaan modalitet indera, bimbingan dalam belajar, kondisi-kondisi intensif.

c. Faktor-faktor individual.

Faktor-faktor individu meliputi; kematangan, faktor usia kronologis, perbedaan jenis kelamin, pengalaman sebelumnya, kapasitas mental, kondisi kesehatan jasmani, kondisi kesehatan rohani, dan motivasi.

\section{METODE PENELITIAN}

\section{Subyek Penelitian}

Subyek yang akan diteliti ialah siswa yang mendapat pembelajaran syarat melukis segitiga kelas VII semester 2 MTs di Kota Semarang. Sedangkan sampel yang akan diambil untuk pelaksanaan penelitian ini adalah MTsN 1 Semarang.

Alasan peneliti mengambil sampel MTsN 1 Kota Semarang adalah:

a. Pembelajaran matematika pokok bahasan syarat melukis segitiga di MTsN 1 Kota Semarang masih menggunakan media 
papan tulis.

b. Hasil tes formatif pokok bahasan syarat melukis segitiga masih di bawah ketuntasan minimal belajar yang ditentukan untuk mata pelajaran matematika di MTsN 1 Kota Semarang yaitu 6,5 .

c. Siswa MTsN 1 Kota Semarang adalah siswa yang hidup didaerah pinggiran kota tentu semangat perjuangan belajarnya tidak begitu besar. Umunya siswa berasal dari orang tua ekonomi menengah ke bawah dan banyak dari mereka setelah pulang dari sekolah membantu orang tua bekerja.

d. Siswa kelas VII sebanyak 9 ( sembilan ) kelas yang dibagi dengan rata-rata kemampuan siswa antar kelas adalah sama. Untuk pelaksanaan penelitian ini akan mengambil dua guru matematika dengan pelaksanaan pra siklus, siklus 1, siklus 2 pada masing-masing guru akan mengambil kelas yang berbeda. Hal ini ditempuh untuk membandingkan proses pembelajaran pada tiap-tiap siklus. Sedangkan pengambilan tiga kelas dengan guru yang sama adalah untuk membandingkan proses pembelajaran pra siklus, siklus 1 dan siklus 2 yang menggunakan model pembelajaran matematika creative problem solving dengan media video compact disk.

\section{Variabel Penelitian.}

Variabel indikator yang akan diamati dalam penelitian ini:

a. Pemahaman konsep tentang syarat melukis segitiga.

b. Keaktifan siswa dalam proses pembelajaran.

c. Hasil belajar siswa.

\section{Metode Pengumpulan Data dan Pengolahan Data}

a. Cara Pengumpulan Data

1) Dokumenter

Metode dokumenter digunakan untuk mengetahui dan mendapatkan daftar nama siswa dari kelas VII MTsN 1 Kota Semarang.

2) Tes

Tes digunakan untuk mendapatkan hasil belajar siswa 
setelah melakukan pembelajaran matematika pokok bahasan syarat melukis segitiga dengan model pembelajaran matematika creative problem solving dengan media video compact disk, baik pada, siklus 1 dan siklus 2 .

3) Lembar kerja

Lembar kerja berupa langkah-langkah untuk memahami konsep syarat melukis segitiga dengan model pembelajaran matematika creative problem solving dengan media video compact disk yang diberikan siswa pada siklus 1 dan siklus 2 .

4) Pengamatan

Pengamatan dilakukan pada tiap siklus. Pengamatan pra siklus sebagai latar belakang terciptanya model pembelajaran matematika creative problem solving dengan media video compact disk, pengamatan siklus 1 dipakai untuk direfleksikan pada siklus 2 .

\section{b. Cara pengolahan Data}

Data hasil pengamatan dan tes diolah dengan analisis deskriptif untuk menggambarkan keadaan peningkatan pencapaian indikator keberhasilan tiap siklus dan untuk menggambarkan keberhasilan pembelajaran dengan model creative problem solving dengan media video compact disk yang dapat meningkatkan pemahaman konsep syarat melukis segitiga, keaktifan dalam pembelajaran, dan hasil belajar siswa.

Sedangkan untuk mengetahui besarnya pengaruh model pembelajaran matematika creative problem solving dengan media video compact disk pada pokok bahasan syarat melukis segitiga terhadap hasil belajar akan diuji regresi dengan menggunakan SPSS.

\section{Metode Penyusunan Instrumen}

\section{a. Rencana Pelaksanaan Pembelajaran (RPP)}

Rencana Pelaksanaan Pembelajaran(RPP) pada siklus 1 dan siklus 2 dibuat berdasarkan format yang disyaratkan dalam kurikulum tingkat satuan pendidikan. Di dalam RPP tertuang skenario pembelajaran matematika dengan pokok bahasan 
syarat melukis segitiga yang menggunakan model pembelajaran matematika creative problem solving dengan media video compact disk.

\section{b. Lembar Kerja/modul}

Lembar kerja dibuat untuk memahami dan mendalami konsep syarat melukis segitiga setelah siswa melihat tayangan VCD pembelajan. Lembar keja ini berupa masalah-masalah yang berhubungan dengan syarat melukis segitiga.

\section{c. Tugas Rumah}

Tugas rumah diberikan soal-soal yang bertujuan untuk mendalami konsep syarat melukis segitiga serta kontekstualnya dalam kehidupan sehari-hari.

\section{d. Instrumen Pengamatan}

Instrumen pengamatan disusun dengan indikator-indikator yang bisa mengukur tercapainya kompetensi dasar pokok bahasan syarat melukis segitiga. Dalam hal ini terutama untuk mengukur selama proses pelaksanaan pembelajarannya, baik mengamati keaktifan siswa, dan pemahaman konsep.

\section{e. Tes Formatif}

Tes formatif dilakukan pada akhir pra siklus, siklus 1 dan siklus 2. Tes formatif pada siklus 1 dipakai untuk melihat keberhasilan sementara pembelajaran dengan menggunakan model pembelajaran matematika creative problem solving dengan media video compact disk, yang akan di bandingkan dengan hasil belajar pada pra siklus dan sebagai evaluasi untuk refleksi pada siklus 2. Sedangkan tes formatif pada siklus 2 untuk melihat keberhasilan model pembelajaran matematika creative problem solving dengan media video compact disk. Soal tes diambil dari soal-saol ebtanas dan tes akhir semester dalam tiga tahun terakhir khusus pada pokok bahasan syarat melukis segitiga. 


\section{Waktu dan Lama Penelitian.}

Penelitian ini dirancang berlangsung selama 6 bulan. Pada 3 bulan pertama akan digunakan untuk persiapan : mengurus perijinan, mempersiapkan pembelajaran; membuat rencana pembalajaran(RPP) yang berisi skenario pembelajaran dengan model pembelajaran matematika creative problem solving dengan media video compact disk, menyusun lembar kerja, membuat media pembelajaran dengan vedio compact disk, menyusun instrument pengamatan dan instrument tes. Dalam hal ini sudah disusun 2 rancangan pembelajaran untuk siklus 1 dan siklus 2 . Pada pelaksanaanya nanti akan dievaluasi pelaksanaan siklus 1 untuk merefleksi rencana siklus yang ke 2. Satu bulan berikutnya melaksanakan tindakan kelas yang dirancang 3 tahap yaitu pra siklus, siklus 1, dan siklus 2. Pada 2 bulan terakhir digunakan untuk menyusun laporan kemajuan penelitian, yang akan diseminarkan. Secara terperinci dapat dilihat pada tabel sebagai berikut:

Tabel 1: Perincian waktu pelaksanaan penelitian.

\begin{tabular}{|l|l|l|l|}
\hline MGG & KEGIATAN & \multicolumn{1}{|c|}{ TEMPAT } & KETERANGAN \\
\hline I-II & Survey & $\begin{array}{l}\text { MTs } \\
\text { di kota } \\
\text { Semarang }\end{array}$ & $\begin{array}{l}\text { Observasi dan } \\
\text { wawancara } \\
\text { terbuka pada guru } \\
\text { matematika }\end{array}$ \\
\hline III-IV & $\begin{array}{l}\text { Penyusunan } \\
\text { instrumen } \\
\text { observasi dan } \\
\text { wawancara } \\
\text { Venganalisis } \\
\text { hasil survey }\end{array}$ & Peneliti & Peneliti \\
\hline
\end{tabular}


Model Pembelajaran Creative Problem Solving ......

\begin{tabular}{|c|c|c|c|}
\hline VI-IX & $\begin{array}{l}\text { Penyusunan } \\
\text { panduan } \\
\text { prototype } \\
\text { model } \\
\text { pembelajaran } \\
\text { matematika } \\
\text { creative problem } \\
\text { solving dengan } \\
\text { media video } \\
\text { compact disk }\end{array}$ & Peneliti & $\begin{array}{l}\text { Dipertajam diskusi } \\
\text { dan lokakarya oleh } \\
\text { peneliti dan guru } \\
\text { matematika MTs. } \\
\text { Di Kota Semarang }\end{array}$ \\
\hline X-XII & $\begin{array}{l}\text { Menyusun } \\
\text { instrumen } \\
\text { pembelajaran } \\
\text { termasuk } \\
\text { membuat } \\
\text { media } \\
\text { pembelajaran } \\
\text { dengan VCD }\end{array}$ & Peneliti & Peneliti \\
\hline $\begin{array}{l}\text { XIII- } \\
\text { XVI }\end{array}$ & $\begin{array}{l}\text { Penerapan } \\
\text { model } \\
\text { pembelajaran } \\
\text { berbasis } \\
\text { turnamen } \\
\text { pada kelas } \\
\text { sebenarnya } \\
\text { (Classroom } \\
\text { Action } \\
\text { Research) }\end{array}$ & $\begin{array}{l}\text { MTsN } \\
1 \text { Kota } \\
\text { Semarang }\end{array}$ & $\begin{array}{l}\text { Dilaksanakan oleh } \\
\text { guru mitra dan } \\
\text { diamati oleh peneliti }\end{array}$ \\
\hline $\begin{array}{l}\text { XVII- } \\
\text { XXIV }\end{array}$ & $\begin{array}{l}\text { Penulisan } \\
\text { laporan dan } \\
\text { seminar }\end{array}$ & Peneliti & Peneliti \\
\hline
\end{tabular}

\section{Siklus Kegiatan.}

Kegiatan dirancang dengan penelitian tindakan kelas. Kegiatan diterapkan dalam upaya menumbuhkan keaktifan siswa 
dalam proses pembelajaran sebagai langkah untuk memahamkan konsep syarat melukis segitiga demi tercapainya kompetensi dasar yang diharapkan.

Tahapan langkah disusun dalam 3 tahap/siklus penelitian yaitu pra siklus, siklus 1, dan siklus 2. Pra siklus dilakukan untuk mengetahui pelaksaan pembelajaran yang belum menggunakan model pembelajaran matematika creative problem solving dengan media video compact disk. Sedangkan siklus 1 dan siklus 2 terdiri atas perencanaan, pelaksanaan, pengamatan, dan refleksi.

Pelaksanaan tiap tahap/siklus akan diambil dua kelas dengan guru matematika yang berbeda. Hal ini ditempuh untuk membandingkan dan menggambarkan proses pembelajaran pada tiap-tiap siklus. Sebagai langkah-langkah besar yang akan dilakukan adalah sebagai berikut:

\section{a. Pra Siklus}

Dalam pra siklus ini peneliti akan melihat pembelajaran matematika pada pokok bahasan syarat melukis segitiga di dua kelas dengan guru yang berbeda. Pada pelaksanaan pra siklus ini kedua guru masih menggunakan yang konvensional yaitu belum menggunakan model pembelajaran matematika creative problem solving dengan media video compact disk.

Dalam plaksanaan pembelajaran pada pra siklus ini juga akan diukur dengan indikator penelitian yaitu akan dilihat keaktifan siswa dalam proses pembelajaran, pemahaman konsep tentang syarat melukis segitiga, serta hasil belajar siswa. Hal ini dilakukan sebagai dasar untuk membandingkan keberhasilan pembelajaran menggunakan model pembelajaran matematika creative problem solving dengan media video compact disk pada siklus 1 dan siklus 2.

\section{b. Siklus 1}

Untuk pelaksanaan siklus 1 juga menggunakan dua kelas dengan guru yang sama pada pelaksanaan pra siklus. Langkahlangkah besar dalam siklus 1 ini mulai dari perencanaan, pelaksanaan, pengamatan dan refleksi akan dijelaskan sebagai berikut:

82 Jurnal PHENOMENON, Volume 1 Nomor 1, Juli 2011 
1) Perencanaan

a) Meninjau kembali rancangan pembelajaran yang telah disiapkan dalam bentuk prototype/modul( RPP, lembar kerja, soal evaluasi, soal tugas rumah). Selain itu perencanaan disini juga menyiapkan siswa benar-benar berada pada suasana penyadaran diri untuk melakukan pemecahan masalah/problem solving yang menekankan pada keaktifan siswa dalam setiap proses pembelajaran dengan menggunakan vedio compact disk. Persiapan ini akan ditemukan terlebih dahulu antara guru dan siswa di luar jam.

b) RPP harus menggambarkan pelaksanaan pembelajaran yang menggunakan model creative problem solving dengan media video compact disk.

c) Lembar kerja yang isinya berupa soal dan prosedur untuk alur pelaksanaan pembelajaran dengan model pembelajaran matematika creative problem solving dengan media video compact disk.

2) Pelaksanaan

Guru mitra dengan didampingi peneliti melaksanakan pembelajaran sesuai dengan RPP yang telah disiapkan oleh peneliti. Adapun langkah-langkah pembelajaran syarat melukis segitiga dengan menggunakan model pembelajaran matematika creative problem solving dengan media video compact disk pada siklus 1 ini secara garis besar adalah sebagai berikut:

a) Guru memberikan apersepsi tentang syarat melukis segitiga secara kontekstual yang ada pada lingkungan siswa.

b) Guru menyampaikan tujuan pembelajaran.

c) Guru memutarkan CD pembelajaran tentang syarat melukis segitiga.

d) Guru memberikan soal/masalah yang berhubungan dengan konsep syarat melukis segitiga.

e) Dengan langkah problem solving siswa diminta untuk menyelesaikan permasalahan tersebut. 
f) Menyamakan persepsi dipandu oleh guru.

g) Menyimpulkan pelaksanaan pembelajaran yang telah dilakukan.

h) Guru melakukan tes formatif secara individual.

3) Pengamatan

Guru dan peneliti melakukan pengamatan:

a) Selama proses pembelajaran untuk mengetahui tentang keaktifan siswa dalam melakukan kegiatan problen solving.

b) Pemahaman konsep dan hasil evaluasi/tes akhir.

c) Dengan mencatat keberhasilan dan hambatan-hambatan yang dialami dalam proses pembelajaran yang belum sesuai dengan harapan penelitian.

4) Refleksi

a) Secara kolaboratif guru mitra dan peneliti menganalisis dan mendiskusikan hasil pengamatan. Selanjutnya membuat suatu refleksi mana yang perlu dipertahankan dan mana yang perlu diperbaiki untuk siklus ke 2 nantinya..

b) Membuat simpulan sementara terhadap pelaksanaan siklus 1.

\section{c. Siklus 2}

Untuk pelaksanaan siklus 2 secara teknis sama dengan pelaksanaan siklus 1. Langkah-langkah besar dalam siklus 2 ini yang perlu ditekankan mulai dari perencanaan, pelaksanaan, pengamatan dan refleksi akan dijelaskan sebagai berikut:

1) Perencanaan

Meninjau kembali rancangan pembelajaran yang disiapkan untuk siklus 2 dengan melakukan revisi sesuai hasil refleksi siklus 1.

2) Pelaksanaan

Guru mitra dengan didampingi peneliti melaksanakan pembelajaran sesuai dengan RPP yang telah disiapkan oleh 
peneliti dan direfisi berdasarkan evaluasi pada siklus 1 . Adapun langkah-langkah pembelajaran model pembelajaran matematika creative problem solving dengan media video compact disk sama dengan langkah-langkah pelaksanaan pembelajaran pada siklus1.

3) Pengamatan

Guru dan peneliti melakukan pengamatan yang sama pada siklus 1.

4) Refleksi

Refleksi pada siklus kedua ini dilakukan untuk melakukan penyempurnaan prototype/modul pembelajaran dengan menggunakan model pembelajaran matematika creative problem solving dengan media video compact disk yang diharapkan dapat menumbuhkan keaktifan siswa dalam proses pembelajaran, meningkatkan pemahaman konsep syarat melukis segitiga, serta meningkatkan hasil belajar siswa.

\section{Indikator Kinerja.}

Tabel 2 : Indikator Keberhasilan siswa dalam pembelajaran

\begin{tabular}{|l|l|l|}
\hline No & Indikator/Variabel & \multicolumn{1}{c|}{ Keterangan } \\
\hline 1 & Keaktifan dalam & • Keaktifan bertanya. \\
& pembelajaran. & • Keaktifan menjawab. \\
& Indikator pencapaian & • Keaktifan menulis. \\
& mencapai 5 kadar & • Keaktifan menyelesaikan \\
& keaktifan diskoring & tugas individu. \\
& dengan skala likert (1 s.d & • Keaktifan menyelesaikan \\
& 5). Indikator pencapaian & tugas dalam kelompok \\
& di atas 60\%. & - Keaktifan menyiapkan alat \\
& & untuk menggambar. \\
\hline
\end{tabular}




\begin{tabular}{|c|c|c|}
\hline 2 & $\begin{array}{l}\text { Pemahaman konsep } \\
\text { syarat menggambar } \\
\text { segitiga. } \\
\text { Indikator pencapaian } \\
\text { diskoring dengan skala } \\
\text { likert (1 s.d 5).Indikator } \\
\text { pencapaian di atas } 60 \% .\end{array}$ & $\begin{array}{ll}\text { - } & \text { Menggunakan jangka untuk } \\
\text { - } & \text { Menggambar } \\
\text { - } & \text { Menggunakan busur untuk } \\
\text { - } & \text { Menggambar sudut. } \\
\text { - } & \text { Menggambar segitiga } \\
\text { yang di ketahuai tiga buah } \\
\text { sisinya. } \\
\text { Menggambar segitiga yang } \\
\text { di ketahuai dua sudut dan } \\
\text { satu sisinya. } \\
\text { Menggambar segitiga yang } \\
\text { di ketahuai dua sisi dan satu } \\
\text { sudut. }\end{array}$ \\
\hline 3 & $\begin{array}{l}\text { Hasil belajar. } \\
\text { Rata-rata nilai yang } \\
\text { dicapai diatas hasil } \\
\text { ketuntasan belajar yang } \\
\text { di tentukan yaitu } 6,0 \text {. }\end{array}$ & $\begin{array}{l}\text { Diadakan tes akhir setelah pra } \\
\text { siklus, siklus } 1 \text { dan siklus } 2 \text {. }\end{array}$ \\
\hline
\end{tabular}

\section{HASIL PENELITIAN DAN PEMBAHASAN}

\section{Pra Siklus.}

Pelaksanaan pembelajaran pra siklus untuk kelas VIIA yang diampu bapak Harjoko, S.Pd dilaksanakan pada hari Jum'at tanggal 30 Mei 2008. Sedang untuk kelas VIIE yang diampu bapak Drs. Purwito dilaksanakan pada hari Sabtu tanggal 31 Mei 2008.

Berdasarkan hasil pengamatan pada pelaksanaan pembelajaran pra siklus Kelas VIIA yang diampu bapak Harjoko, S.Pd. dalam proses pembelajarannya masih menggunakan metode ceramah. Guru mengawali dengan menjelaskan materi syarat menggambar segitiga sambil menuliskan dipapan tulis. Saat guru menjelaskan murid diminta untuk mendengarkan dan kalau ada hal-hal yang dirasa tidak mengerti, siswa bisa langsung 
bertanya pada guru. Setelah guru selesai menjelaskan tentang materi murid diminta mencatat apa yang telah ditulis guru dipapan tulis.

Untuk pelaksanaan pembelajaran selanjutnya guru memberikan contoh soal yang berhubungan dengan syarat menggambar segitiga. Dari soal tersebaut diselesaikan oleh guru dipapan tulis dengan siswa memperhatikan apa yang dikerjakan oleh guru. Kemudian murid menyalin penyelesaian dari papan tulis ke buku tulis masing-masing.

Baru kemudian guru memberikan soal tentang syarat menggambar segitiga untuk diselesaikan murid. Dengan memberikan selang waktu sekitar 15 menit siswa mengerjakan soal masing-masing. Setelah ditawarkan bagi yang bisa untuk maju, baru ada siswa yang maju untuk mengerjakan soal tersebut dipapan tulis dan hasilnya dikoreksi bersama dengan guru. Pada waktu menjelang akhir pelaksanaan pembelajaran diadakan tes akhir.

Untuk pelaksanaan proses pembelajaran kelas VIIE yang diampu bapak Drs. Purwito juga menunjukan kondisi kelas hampir sama persis dengan kondisi kelas VIIA. Guru menjelaskan materi sambil menulis dipapan tulis dengan murid mendengarkan, murid mencatat, guru memberi contoh soal dan menyelesaikan, murid mencatat, mengerjakan soal, tes akhir.

a. Keaktifan Siswa Dalam Proses Pembelajaran.

Untuk hasil penilaian secara individu yang dilihat dari indikator keaktifan siswa dalam proses pembelajaran pada pra siklus dapat dilihat di lampiran 6, kalau kita lihat rata-rata prosentasenya adalah seperti yang terlihat pada tabel berikut:

Rata-rata Prosentase Penilaian Keaktifan Siswa Pra Siklus

\begin{tabular}{|c|c|}
\hline GURU & PRA SIKLUS \\
\hline Harjoko, S.Pd & $52,75 \%$ (VIIA) \\
\hline Drs. Purwito & $54,58 \%$ (VIIE) \\
\hline
\end{tabular}

Dari hasil pengamatan keaktifan siswa dalam proses pembelajaran pra siklus baik kelas VIIA yang diampu oleh bapak Har- 
joko, S.Pd dan kelas VIIE yang diampu oleh bapak Drs. Purwito ( lampiran 6 ) dapat disimpulkan bahwa siswa belum terlibat aktif dalam proses pembelajaran. Siswa masih banyak mendengarkan dalam memahami konsep syarat menggambar segitiga. Sehingga dalam proses pembelajaran siswa masih bergantung pada guru. Hal ini juga ditunjukan dari rata-rata prosentasi hasil penilaian keaktifan siswa kelas VIIA adalah 52,75 \% dan kelas VIIE $54,58 \%$ yang masih berada dibawah ketentuan yaitu $60 \%$.

b. Pemahaman Konsep.

Untuk hasil penilaian secara individu yang dilihat dari indikator pemamahan konsep siswa dalam proses pembelajaran pada pra siklus ( lampiran 6 ) adalah sebagai berikut:

\section{Rata-rata Prosentase Penilaian \\ Pemahaman Konsep Siswa \\ Pra Siklus}

\begin{tabular}{|l|l|}
\hline GURU & PRA SIKLUS \\
\hline Harjoko, S.Pd & $56,71 \%($ VIIA) \\
\hline Drs. Purwito & $55,86 \%($ VIIE) \\
\hline
\end{tabular}

Dari hasil pengamatan pemahaman konsep siswa dalam proses pembelajaran pra siklus baik kelas VIIA yang diampu oleh bapak Harjoko, S.Pd dan kelas VIIE yang diampu oleh bapak Drs. Purwito ( lampiran 6 ) dapat disimpulkan bahwa siswa belum memperoleh pemahaman tentang syarat menggambar segitiga. Hal ini ditandai dengan tidak bisanya siswa dalam membaca busur derajat, belum bisa menggambar segitiga dengan benar jika dihadapkan pada permasalahan yang baru. Selain itu juga dapat dilihat dari rata-rata prosentase hasil penilaian pemahaman konsep syarat menggambar segitiga yaitu untuk kelas VIIA adalah 56,71 \% dan kelas VIIE 55,86\% yang masih berada dibawah ketentuan yaitu $60 \%$.

c. Hasil Belajar Siswa.

Setelah akhir pembelajaran diadakan tes akhir yang hasil- 
nya ( lampiran 6 ) secara rata-rata dapat dilihat sebagai berikut:

\section{Rata-rata Nilai Tes Akhir}

Pra Siklus

\begin{tabular}{|c|c|}
\hline GURU & PRA SIKLUS \\
\hline Harjoko, S.Pd & 53,075 (VIIA) \\
\hline Drs. Purwito & $52,5($ VIIE) \\
\hline
\end{tabular}

Dari nilai rata-rata hasil belajar siswa dalam pembelajaran pra siklus baik kelas VIIA yang diampu oleh bapak Harjoko, S.Pd dan kelas VIIE yang diampu oleh bapak Drs. Purwito ( lampiran 6 ) dapat disimpulkan masih dibawah hasil ketuntasan belajar yan ditentukan yaitu 60. Hal ini juga bisa dilihat dari hasil kelas VIIA yang belum tuntas belajar sebanyak 30 siswa. Sedangkan kelas VIIE yang belum tuntas belajar sebanyak 31 siswa.

\section{Siklus 1}

Pelaksanaan pembelajaran siklus 1 untuk kelas VIIB yang diampu bapak Harjoko, S.Pd dilaksanakan pada hari Rabu tanggal 4 Juni 2008. Sedang untuk kelas VIIF yang diampu bapak Drs. Purwito dilaksanakan pada hari Sabtu tanggal 7 Juni 2008. Dari hasil pembelajaran siklus 1 yang dilihat dari 3 indikator keberhasilan adalah sebagai berikut:

a. Keaktifan Siswa Dalam Proses Pembelajaran.

Rata-rata Prosentase Penilaian Keaktifan Siswa Pra Siklus \& Siklus 1

\begin{tabular}{|c|c|c|}
\hline GURU & PRA SIKLUS & SIKLUS 1 \\
\hline Harjoko, S.Pd & $52,75 \%$ (VIIA) & $63,25 \%$ (VIIB) \\
\hline Drs. Purwito & $54,58 \%$ (VIIE) & $66,84 \%($ VIIF) \\
\hline
\end{tabular}

Dari hasil pengamatan keaktifan siswa dalam proses pembelajaran siklus 1 baik kelas VIIB yang diampu oleh bapak Harjoko, S.Pd dan kelas VIIF yang diampu oleh bapak Drs. Purwito( lampiran 6 ) dapat disimpulkan bahwa siswa sudah mulai terlibat aktif dalam proses pembelajaran walaupun belum optimal 
sesuai dengan harapan. Siswa sudah banyak yang terlihat aktif bertanya, menjawab pertanyaan, menulis, menyelesaikan masalah baik individu dan kelompok. Sehingga dalam proses pembelajaran siswa sudah tidak lagi bergantung pada guru. Hal ini juga ditunjukan dari rata-rata prosentasi hasil penilaian keaktifan siswa kelas VIIB adalah 63,25 \% dan kelas VIIF 66,84\% yang sudah berada di atas ketentuan yaitu $60 \%$.

b. Pemahaman konsep.

Rata-rata Prosentase Penilaian Pemahaman Konsep

Pra Siklus \& Siklus 1

\begin{tabular}{|c|c|c|}
\hline GURU & PRA SIKLUS & SIKLUS 1 \\
\hline Harjoko, S.Pd & $56,71 \%($ VIIA) & $64,93 \%($ VIIB) \\
\hline Drs. Purwito & $55,86 \%($ VIIE) & $66,74 \%($ VIIF) \\
\hline
\end{tabular}

Dari hasil pemecahan masalah dan pengamatan dalam proses pembelajaran siklus 1 baik kelas VIIB yang diampu oleh bapak Harjoko, S.Pd dan kelas VIIF yang diampu oleh bapak Drs. Purwito ( lampiran 6 ) dapat disimpulkan bahwa siswa sudah mulai memhami konsep syarat menggambar segitiga. Hal ini ditandai dengan sudah bisa membaca busur derajat, dapat menggunakan jangka dalam menggambar sudut, dapat menggambar segitiga jika diketahui ketiga sisinya, dapat menggambar segitiga jika diketahui dua sudut dan satu sisi, dapat menggambar segitiga jika diketahui dua sisi dan satu sudut walaupun belum optimal. Hal ini juga ditunjukan dari rata-rata prosentasi hasil penilaian pemahaman konsep siswa kelas VIIB adalah 64,93 \% dan kelas VIIF 66,74 $\%$ yang sudah berada di atas ketentuan yaitu $60 \%$.

c. Hasil Belajar Siswa.

Setelah akhir pembelajaran diadakan tes akhir yang hasilnya ( lampiran 6 ) didapat sebagai berikut: 
Rata-rata Nilai Tes Akhir

Pra Siklus \& Siklus 1

\begin{tabular}{|l|l|l|}
\hline GURU & PRA SIKLUS & SIKLUS 1 \\
\hline Harjoko, S.Pd & 53,075 (VIIA) & $63,78($ VIIB) \\
\hline Drs. Purwito & 52,5 (VIIE) & $68,31($ VIIF) \\
\hline
\end{tabular}

Dari nilai rata-rata hasil belajar siswa dalam pembelajaran siklus 1 baik kelas VIIB yang diampu oleh bapak Harjoko, S.Pd dan kelas VIIF yang diampu oleh bapak Drs. Purwito ( lampiran 6 ) dapat disimpulkan sudah berada di atas hasil ketuntasan belajar yan ditentukan yaitu 60. Hal ini juga bisa dilihat dari hasil kelas VIIB yan belum tuntas belajar sebanyak 17 siswa. Sedangkan kelas VIIF yang belum tuntas belajar sebanyak 9 siswa.

Jika dibandingkan dengan hasil pembelajaran pra siklus yang masih menggunakan metode ceramah, pada siklus 1 ini yang sudah menggunakan metode problem solving dengan menggunakan VCD dari hasil belajar siswa menunjukan adanya peningkatan.

Dari hasil evaluasi siklus 1 menghasilkan beberapa catatan yang harus direfleksikan pada pelaksanaan pembelajaran siklus 2 yaitu sebagai berikut:

1. Guru kurang menguasai skenario pembelajaran, sehingga perjalanan pembelajaran model problem solving dengan menggunakan VCD belum lancar/optimal.

2. Guru kurang memberikan bimbingan pada tiap-tiap kelompok saat menyelesaikan masalah.

3. Murid belum diberitahu sebelumnya untuk mempelajari materi syarat menggambar segitiga.

4. Masih ada beberapa murid yang pasif.

5. Ada beberapa murid yang trobel maker dalam kelompoknya.

6. VCD macet saat pemutaran $\mathrm{CD}$ pembelajaran sehingga menyita waktu. 


\section{Siklus 2}

Setelah melakukan evaluasi dari hasil siklus 1, maka modul yang berupa RPP dan Lembar Kerja siklus 2 diadakan refisi-refisi. Pelaksanaan pembelajaran siklus 2 untuk kelas VIIC yang diampu bapak Harjoko, S.Pd dilaksanakan pada hari Senin tanggal 9 Juni 2008. Sedang untuk kelas VIIG yang diampu bapak Drs. Purwito dilaksanakan pada hari Selasa tanggal 10 Juni 2008. Dari hasil pembelajaran siklus 2 ini yang dilihat dari 3 indikator keberhasilan adalah sebagai berikut:

a. Keaktifan Siswa Dalam Proses Pembelajaran.

\section{Rata-rata Prosentase Penilaian Keaktifan Siswa Pra Siklus, Siklus 1 \& Siklus 2}

\begin{tabular}{|l|c|c|c|}
\hline GURU & PRA SIKLUS & SIKLUS 1 & SIKLUS 2 \\
\hline \multirow{2}{*}{ Harjoko, S.Pd } & $\begin{array}{c}52,75 \% \\
\text { (VIIA) }\end{array}$ & $\begin{array}{c}63,25 \% \\
\text { (VIIB) }\end{array}$ & $\begin{array}{c}77,48 \% \\
\text { (VIIC) }\end{array}$ \\
\hline \multirow{2}{*}{ Drs. Purwito } & $54,58 \%$ & $66,84 \%$ & $77,42 \%$ \\
& (VIIE) & (VIIF) & (VIIG) \\
\hline
\end{tabular}

Dari hasil pengamatan keaktifan siswa dalam proses pembelajaran siklus 2 baik kelas VIIC yang diampu oleh bapak Harjoko, S.Pd dan kelas VIIG yang diampu oleh bapak Drs. Purwito ( lampiran 6 ) dapat disimpulkan bahwa siswa sudah semuanya terlibat aktif dalam proses pembelajaran. Siswa secara individu hampir keseluruhan terlihat aktif bertanya, menjawab pertanyaan, menulis, menyelesaikan tugas baik individu dan kelompok. Sehingga dalam proses pembelajaran siswa sudah tidak lagi bergantung pada guru. Hal ini juga ditunjukan dari ratarata prosentasi hasil penilaian keaktifan siswa kelas VIIC adalah 77,48 \% dan kelas VIIG 77,42 \% yang sudah berada di atas ketentuan yaitu $60 \%$.

Jika dibandingkan dengan siklus 1, keaktifan siswa di siklus 2 ini sudah menunjukan adanya peningkatan. 
b. Pemahaman Konsep

Rata-rata Prosentase Penilaian Pemahaman Konsep

Pra Siklus, Siklus 1 \& Siklus 2

\begin{tabular}{|c|c|c|c|}
\hline GURU & PRA SIKLUS & SIKLUS 1 & SIKLUS 2 \\
\hline \multirow{2}{*}{ Harjoko, S.Pd } & $56,71 \%$ & $64,95 \%$ & $78,84 \%$ \\
& (VIIA) & (VIIB) & (VIIC) \\
\hline \multirow{2}{*}{ Drs. Purwito } & $55,86 \%$ & $66,74 \%$ & $78,29 \%$ \\
& (VIIE) & (VIIF) & (VIIG) \\
\hline
\end{tabular}

Dari hasil pengamatan ketrampilan bermain peran siswa dalam proses pembelajaran siklus 2 baik kelas VIIC yang diampu oleh bapak Harjoko, S.Pd dan kelas VIIG yang diampu oleh bapak Drs. Purwito ( lampiran 6 ) dapat disimpulkan bahwa secara individu siswa sudah memahami konsep syarat menggambar segitiga. Hal ini ditandai dengan sudah bisa membaca busur derajat, dapat menggunakan jangka dalam menggambar sudut, dapat menggambar segitiga jika diketahui ketiga sisinya, dapat menggambar segitiga jika diketahui dua sudut dan satu sisi, dapat menggambar segitiga jika diketahui dua sisi dan satu sudut secara optimal Hal ini juga ditunjukan dari rata-rata prosentasi hasil penilaian ketrampilan bermain peran siswa kelas VIIB adalah 78,84 \% dan kelas VIIF 78,29 \% yang masih sudah berada di atas ketentuan yaitu $60 \%$.

Jika dibandingkan dengan siklus 1, pada siklus 2 ini telah mengalami peningkatan.

c. Hasil Belajar Siswa.

Rata-rata Nilai Tes Akhir

Pra Siklus, Siklus 1 \& Siklus 2

\begin{tabular}{|c|c|c|c|}
\hline GURU & PRA SIKLUS & SIKLUS 1 & SIKLUS 2 \\
\hline \multirow{2}{*}{ Harjoko, S.Pd } & $\begin{array}{c}53,075 \\
\text { (VIIA) }\end{array}$ & $\begin{array}{c}63,78 \\
\text { (VIIB) }\end{array}$ & $\begin{array}{c}76,86 \\
\text { (VIIC) }\end{array}$ \\
\hline \multirow{2}{*}{ Drs. Purwito } & 52,5 & 68,31 & 77,025 \\
& (VIIE) & (VIIF) & (VIIG) \\
\hline
\end{tabular}


Dari nilai rata-rata hasil belajar siswa dalam pembelajaran siklus 2 baik kelas VIIB yang diampu oleh bapak Harjoko, S.Pd dan kelas VIIF yang diampu oleh bapak Drs. Purwito ( lampiran 6 ) dapat disimpulkan sudah berada jauh di atas hasil ketuntasan belajar yang ditentukan yaitu 60 .

Jika dibandingkan dengan hasil pembelajaran siklus 1, pada siklus 2 ini sudah menunjukan adanya peningkatan.

Jika dilihat dari hasil kelas VIIC yang belum tuntas belajar 1 siswa yaitu Dhiratun Nasih, ternyata anak tersebut memang agak lemah berfikir.

d. Pengaruh Model Pembelajaran Problem Solving dengan menggunakan VCD Terhadap Hasil Belajar Siswa.

Selain mengambarkan proses dan keberhasilan metode turnamen matematika dengan cara diskriptif, peneliti juga mencoba untuk menghitung besarnya pengaruh metode turnamen matematika terhadap hasil belajar siswa yang dihitung dengan menggunakan SPSS( lampiran 7 ). Dari hasil penghitungan untuk kelas yang diampu oleh Bp. Harjoko, S.Pd menunjukan adanya pengaruh model pembelajaran problem solving dengan menggunakan VCD terhadap hasil belajar siswa sebesar 49,3\%. Sedangkan untuk kelas yan diampu oleh Bp. Drs. Purwito menunjukan adanya pengaruh sebesar $67,7 \%$.

\section{E. PENUTUP}

Dari paparan di atas dapat disimpulkan bahwa: pertama, skenario pembelajaran model problem solving dengan menggunakan VCD pada pokok bahasan syarat menggambar segitiga yang operasional adalah skenario pembelajaran yang dapat meningkatkan keaktifan, pemahaman konsep dan hasil belajar siswa kelas VII MTs. Kedua, pembelajaran model problem solving dengan menggunakan VCD pada pokok bahasan syarat menggambar segitiga dapat meningkatkan keaktifan, pemahaman konsep dan hasil belajar siswa kelas VII MTs. 


\section{DAFTAR PUSTAKA}

Darhim. 1993. Work Shop Matematika. Jakarta: Depdikbud Direktorat Jenderal Pendidikan Dasar dan Menengah Bagian Proyek Penataran Guru SLTP Setara DIII.

Departemen Pendidikan Nasional Direktorat Jenderal Pendidikan Dasar dan Menengah Direktorat Pendidikan Lanjutan Pertama. 2003. Kurikulum 2004 Sekolah Menengah Pertama. Pedoman Khusus Pengembangan Silabus Berbasis Kompetensi Sekolah Menengah Pertama Mata Pelajaran Matematika. Jakarta: Direktorat Jenderal Perguruan Tinggi Depdiknas.

Dimyati, Mudjiono. 1994. Belajar dan Pembelajaran. Jakarta:Direktorat Jenderal Perguruan Tinggi Depdikbud.

Hidayat. 2004. Diktat Kuliah Teori Pembelajaran Matematika. Semarang:FMIPA UNNES.

Pandoyo. 1992. Strategi Belajar Mengajar. Semarang:IKIP Semarang Press.

Permen NO 22 tahun 2005 tentang SK dan KD.

Pepkin K.L. 2004. Creative Problem Solving In Math. Tersedia di: http://www.uh.edu/hti/cu/2004/v02/04.htm [5 Januari 2005].

Suhito. 1990. Strategi Pembelajaran Matematika.Semarang:FPMIPA IKIP Semarang.

Suyitno Amin, Pandoyo, Hidayah Isti, Suhito, Suparyan. 2000. Dasar-dasar dan Proses Pembelajaran Matematika I. Semarang:Pendidikan Matematika FMIPA UNNES

. 2004. Pemilihan Model-model Pembelajaran dan Penerapannya di Sekolah. Semarang:Pendidikan Matematika 
Saminanto

\section{FMIPA UNNES}

Wibawanto H. 2004. Multimedia Untuk Presentasi. Semarang:Laboratorium Komputer Pascasarjana UNNES.

Nuriana R.D, SPd, MPd 2007. Makalah tentang Model Pembelajaran Creative Problem Solving dengan Video Compact Disk dalam Pembelajaran Matematika.Tersedia di: http://www.mathematic.transdigit.com[20 september 2007]. 